\title{
ANALISIS PERENCANAAN PENGEMBANGAN KELAS INTERNASIONAL TERKEMUKA PADA YAYASAN PENDIDIKAN BUDI LUHUR
}

\author{
Rob Sosiatri ${ }^{1)}$ \\ 1) dosen universitas pamulang, email : ruby.a2010@yahoo.com
}

\section{ARTICLES INFORMATION}

\section{JURNAL ILMIAH MANAJEMEN FORKAMMA}

\author{
Vol.1, No.3, Mei 2018 \\ Halaman : 48-60 \\ (c) LPPM \& FORKAMMA \\ Prodi Magister Manajemen \\ UNVERSITAS PAMULANG \\ ISSN (online) : 2599-171X \\ ISSN (print) : :2598-9545
}

\section{Keyword :}

product quality. service quality. customer satisfaction

JEL. classification :

C33, G20, G23, N65

\section{Contact Author : \\ PRODI \\ MAGISTER MANAJEMEN \& FORKAMMA UNPAM \\ JL.Surya Kencana No.1 Pamulang \\ Tangerang Selatan - Banten \\ Telp. (021) 7412566, Fax (021) 7412491 \\ Email : \\ jurnalforkamma.unpam@gmail.com}

Tujuan penelitian ini adalah untuk merencanakan pengembangan kelas internasional terkemuka pada yayasan pendidikan Budi Luhur khususnya dan program kelas internasional di institusi atau lembaga pendidikan lain. Metode penelitian yang digunakan adalah metode kualitatif dengan menggunakan metode AHP (Analytic Hierarchy Process) terdiri dari 3 bagian/variabel, kriteria, alternatif dan faktor yang bertujuan untuk mendapatkan informasi guna penarikan kesimpulan dan pengambilan keputusan tentang perencanaan pengembangan Kelas Internasional di Universitas Budi Luhur. Teknik pengambilan data melalui kuesioner yang disebar ke 6 experts/informan. Teknik analisis data dilakukan setelah data terkumpul dengan cara melakukan uji konsistensi. Hasil analisis data dapat disimpulkan bahwa : prioritas yang paling penting untuk mengembangkan kelas internasional atau global reputation adalah networking, dana dan metode pembelajaran; Prioritas yang paling penting untuk faktor SDM adalah kompetensi profesional; kompetensi pedagogik dan kompetensi sosial; faktor sarana dan prasarana adalah air conditioner, liquid crystal display (LCD), dan papan tulis; faktor kurikulum adalah komponen strategi proses belajar mengajar (PBM), komponen evaluasi dan komponen isi/materi pembelajaran.

The Analysis of the development planning of leading International class at Budi Luhur Education Foundation. The criteria consists of a national and global reputation, an alternative consisting of human resources, curriculum, infrastructure and facilities. Data sources consist of six informants. Based on the analysis of the research data it can be conclude that : the most important priorities for developing international class at the national or global reputation is networking, funding and methods of learning : for human resource, factors are professional competence, pedagogical, and social competence: for infrastructure factors are water conditioners, liquid crystal display (LCD), and whiteboard: for curriculum, factors are components of teaching and learning strategis, components of evaluation and contents/ learning material : for learning methods are problem solving, discussions, question and answer methods : for fund is society, government and companies : for networking includes universities, companies and alumni. 


\section{A. Pendahuluan}

Pendidikan merupakan hal yang wajib didapatkan dan ditempuh oleh setiap manusia di dunia ini. Berbekal pendidikan manusia mampu menghadapi masalah dan tantangan hidup yang sedang atau akan mereka hadapi. Besarnya tentangan hidup juga sangat mempengaruhi tingkat pengetahuan yang harus dimiliki oleh setiap manusia tersebut. Jika manusia memiliki tingkat pengetahuan yang memadai, maka manusia tersebut diharapkan akan mampu didalam menghadapi masalah hidupnya, akan tetapi sebaliknya jika manusia tidak memiliki ilmu dan pengetahuan maka akan menghadapi kesulitan dalam memecahkan permasalah.

Pendidikan di Universitas dilaksanakan sesuai dengan tujuan pendidikan nasional dan di breakdown ke dalam renstra visi misi universitas dan fakultas sampai ke prodi. Masing-masing prodi dalam suatu universitas juga berusaha meningkatkan kualitas mutu pendidikannya agar masyarakat atau stakeholder memiliki kepercayaan pada civitas akademi. Mereka sangat membutuhkan lulusan dari peguruan tinggi yang memiliki capacity atau kemampuan dalam bidangnya. Sehingga yang sebenarnya yang perlu diperhatikan oleh sebuah institusi adalah jumlah lulusan yang berkualitas bukan kuantitas. Jika kuantitasnya banyak akan tetapi yang diterima oleh pasar sedikit dikarenakan kualitas dan spesifikasi lulusan yang tidak masuk kriteria maka pendidikan yang dilakukan disebuah institusi tersebut kurang efektif.

Pendidikan tinggi sebagai ujung tombak dan parameter suatu negara sudah sebenarnya tanggap terhadap perkembangan lingkungan eksternal dan trend yang berkembang di masyarakat. Adanya otonomi kampus, perguruan tinggi dapat menyelenggarakan program-program yang bersifat khusus untuk merespon tuntuan stakeholder salah satunya adalah dengan penyelenggaraan kelas internasional.

Globalisasi yang sedang dan terus berlangsung ini meningkatkan persaingan diberbagai bidang, termasuk sektor ketenagakerjaan. Perkembangan pesat dalam teknologi telekomunikasi telekomunikasi dan informatika (ICT) dan semakin luasnya jangkauan sarana dan perasarana transportasi mengakibatkan lalu lintas tenaga kerja (human capital) antar negara semakin meningkat. Sebagaimana persaingan pada sektor -sektor lainnya, manfaat dari situasi seperti ini akan lebih banyak dinikmati oleh negaranegara maju yang memiliki sumber daya manusia lebih berkualitas. Dalam situasi seperti ini ke unggulan komparatif (comparative advantage) saja tidak cukup, dibutuhkan juga keunggulan kompetitif (competitive advantage) tenaga kerja yang akan memasuki persaingan pasar tenaga kerja. Untuk itu kita perlu membekali ddiri dengan kemampuan akademis maupun praktis agar menjadi tenaga kerja yang tangguh yang terus dapat bertahan dalam persaingan, khususnya dalam meningkatkan karier ataupun sebagai pebisnis.

Globalisasi tersebut pada akhirnya menuntut masyarakat dunia untuk terus beradaptasi dengan berbagai kemungkinan perubahan yang setiap saat bisa terjadi. Masyarakat diberbagai belahan dunia dituntut untuk lebih cerdas memanfaatkan peluang dan menghindari berbagai ancaman yang diakibatkan oleh cepatnya perubahanperubahan tersebut. Kemampuan mengantisipasi berbagai perubahan menjadi salah satu modal dasar suatu bangsa untuk mampu bersaing di level internasional. Setiap negara menyadari bahwa saat ini penyediaan dan pemberdayaan sumber manusia yang handal menjadi sangat penting secara nasional maupun internasional.

Hal utama yang harus dipenuhi jika institusi atau kita akan menjadi warga internasional adalah bahwa setiap prilaku atau life style kita hendakanya sesuai dengan masyarakat didunia internasional dengan tidak membedakan etnis, suku maupun ras dari sisi pola pikir maupun prilaku akan tetapi, budaya daerah atau bangsa yang masih melekat harus tetap dijaga dan dipromosikan dengan cara-cara yang sesuai. Hal tersebut akan menunjukkan eksistensi seseorang atau institusi yang akan bersaing didunia internasional. Sumber daya manusia di universitas, yaitu dosen/tenaga pendidik, mahasiswa/peserta didik dan staf administrasi dari ketiga unsur tersebut harus bersinergi 
dalam memiliki komitmen bersama untuk mewujudkan lulusan yang berkualitas. Untuk mewujudkan cita-cita negara negara tercinta ini, dan dalam rangka adaptif dan antisipasif terhadap perubahan yang terjadi di era globalisasi, maka pengembangan dan peningkatan kualitas sumber daya manusia harus menjadi fokus perhatian bersama, salah satunya adalah dengan meningkatkan kualitas pendidikan.

Menurut Martinis (2010.67) ada beberapa langkah umum pengambilan keputusan, yaitu mendefinisi masalah, menganalisa masalah, mengembangkan alternatif solusi, memutuskan solusi dan memindahkan keputusan ke dalam tindakan efektif. Berdasarkan uraian diatas, maka penulis tertarik mengambil judul: "Analisis Perencanaan Pengembangan Kelas Internasional Terkemuka pada Yayasan Pendidikan Budi Luhur".

\section{B. Perumusan Masalah}

Berdasarkan uraian diatas, maka penulis mencoba merumuskan masalah penelitian ini adalah sebagai berikut: Perencanaan Pengembangan Kleas Internasional Terkemuka di Universitas Budi Luhur Jakarta dengan menggunakan metode AHP sehingga dapat mengambil keputusan secara tepat dan efektif.

\section{Landasan Teori}

\section{Perencanaan}

Definisi perencanaan tersebut menjelaskan bahwa perencanaan merupakan suatu proses untuk mencapai tujuan perusahaan secara menyeluruh dengan menggunakan beberapa aspek, yakni :

1. Penentuan tujuan yang akan dicapai

2. Memilih dan menentukan cara yang akan ditempuh untuk mencapai tujuan atas dasar alternatif yang dipilih.

3. Usaha-usaha atau langkah-langkah yang ditempuh untuk mencapai tujuan atas dasar alternatif yang dipilih.

Selain aspek tersebut, perencanaan juga mempunyai manfaat bagi perusahaan sebagai berikut :

a. Dengan adanya perencanaan, maka pelaksanaan kegiatan dapat dicapai dengan efektif dan efisien.

b. Dapat mengatakan bahwa tujuan yang telah ditetapkan tersebut, dapat dicapai dan dapat dilakukan koreksi atas penyimpangan - penyimpangan yang timbul seawal mungkin.

c. Dapat mengidentifikasi hambatan-hambatan yang timbul dengan meengatasi hambatan dan ancaman

d. Dapat menghindari adanya kegiatan pertumbuhan dan perubahan yang tidak terarah dan terkontrol.

Setelah perencanaan maka kepala sekolah/rektor/manajer bertindak sebagai pengambil keputusan. Martinis (2010.67) ada beberapa langkah umum pengambilan keputusan, yaitu mendefinisi masalah, menganalisa masalah, mengembangkan alternatif solusi, memutuskan solusi dan memindahkan keputusan ke dalam tindakan efektif. Sesuai dengan judul tesis ini yaitu Analisis Perencanaan Pengembangan Kelas Internasional Terkemuka pada Yayasan Pendidikan Budi Luhur, maka pihak manajemen Universitas Budi Luhur harus melakukan langkah-langkah perencanaan yang matang dalam rangka mewujudkan kelas internasional berkualitas/terkemuka di Universitas Budi Luhur.

\section{Pengembangan}

Kata "pengembangan" dalam kamus Bahasa Indonesia berarti suatu perubahan menjadi bertambah sempurna dalam hal pikiran atau akal, pengetahuan, dan lain 
sebagainya. Sugiono (2004:6) menyatakan pengembangan adalah memperdalam dan memperluas pengetahuan yang sudah ada. Pengembangan adalah kegiatan ilmu pengetahuan yang telah terbukti kebenarannya untuk meningkatkan fungsi, manfaat dan aplikasi ilmu pengetahuan dan teknologi yang telah ada, atau menghasilkan teknologi baru.

Malayu Hasibuan, dalam bukunya Manajemen Sumber Daya Manusia (2002:86), penilaian prestasi kerja adalah evaluasi yang sistimatis terhadap pekerjaan yang telah dilakukan oleh karyawan dan ditujukan untuk pengembangan. Pengembangan adalah suatu usaha untuk meningkatkan kemampuan teknis, teoritis, konseptual, dan moral karyawan sesuai dengan kebutuhan pekerjaan/jabatan melalui pendidikan dan latihan. Pendidikan meningkatkan keahlian teoritis, dan konseptual, dan moral karyawan, sedangkan latihan bertujuan untuk meningkatkan keterampilan teknis pelaksanaan pekerjaan karyawan, workshop bagi karyawan dapat meningkatkan pengetahuan lebih lagi di luar perusahaan.

Hasibuan (2002:11) mendefinisikan pengembangan sebagai berikut : "Pengembangan mengacu pada masalah staf dan personel adalah suatu proses pendidikan jangka panjang menggunakan suatu prosedur yang sistematis dan terorganisasi dengan manajer belajar pengetahuan konseptual dan teoritis untuk tujuan umum". Sedangkan definisi latihan diungkapkan oleh Andrew F. Sikula (2001:87) yaitu "latihan adalah proses pendidikan jangka pendek dengan menggunakan prosedur yang sistematis dan terorganisir, sehingga karyawan operasional belajar pengetahuan teknik pengerjaan dan keahlian untuk tujuan tertentu".

\section{Metode AHP ( Analytic Hierarchy Process)}

Metode Analytic Hierarchy Process (AHP) dikembangkan oleh Thomas Lorie Saaty Pittsburg University pada awal tahun 1970. AHP ini merupakan metode yang bisa dipakai untuk mengambil keputusan dengan efektif atas persoalan yang kompleks dengan cara menyederhanakan dan mempercepat proses pengambilan keputusan dengan memecahkan persoalan tersebut kedalam bagian-bagiannya, menata bagian atau variabel ini dalam suatu susunan hierarki, lalu memberi nilai numerik atau disebut bobot berdasarkan pertimbangan subjektif tentang pentingnya tiap variabel dan mensintesis berbagai pertimbangan ini untuk menetapkan variabel yang mana yang memiliki prioritas paling tinggi dan bertindak untuk mempengaruhi hasil pada situasi tersebut.

Dalam AHP ini yang terpenting pertama yang harus dilakukan adalah menentukan goal, apa yang menjadi tujuan kita dalam pengambilan keputusan tersebut. Setelah kita tahu tujuannya, lalu kita menentukan kriteria. Maksudnya adalah kita menentukan apa saja yang menjadi kriteria yang tepat untuk permasalahan yang dihadapi. Setelah kita mendapatkan kriteria-kriteria apa saja yang akan menjadi dasar pertimbangan dalam mengambil keputusan tersebut, selanjutnya adalah mencari option atau pilih-pilih dari keputusan yang akan kita ambil, dengan berdasarkan pada kriteria - kriteria yang telah kita tentukan sebelumnya.

\section{Metodologi Penelitian}

Jenis penelitian merupakan penelitian kualitatif dengan mengunakan metode AHP (Analityc Hierarchy Process) yang bertujuan untuk mendapatkan informasi guna penarikan kesimpulan dan pengambilan keputusan tentang perencanaan pengembangan kelas internasional di Universitas Budi Luhur Jakarta.

\section{Teknik Pengumpulan Data}

Pengumpulan data dalam pengertian ini diperoleh melalui pengisian kuesioner. Instrumen penelitian (kuesioner) merupakan alat yang dipakai oleh peneliti untuk 
menjembatani sejauh mana data mencerminkan konsep yang ingin diukur tergantung pada instrumen (yang substansinya disusun berdasarkan penjabaran konsep/penentuan kriteria, alternatif dan faktor) yang dipergunakan untuk mengumpulkan data. Tujuan pembuatan kuesioner ini oleh peneliti untuk memperoleh informasi yang relevan dengan tujuan penelitian.

\section{E. Hasil Penelitian}

Berikut hasil Penelitian untuk menentukan urutan prioritas alternatif dan urutan prioritas dari faktor alternatif dengan menggunakan metode AHP (Analytical Hierarchy Process) pada Perencanaan Pengembangan Kelas Internasional Terkemuka di Yayasan Pendidikan Budi Luhur.

1. Penentuan Urutan Berdasarkan Informan

a. Kriteria Global Reputation

Berikut ini adalah tabel urutan hasil dari hitungan kuesioner untuk kriteria global reputation;

Tabel 4.1

Kriteria Global Reputation

\begin{tabular}{|c|c|c|c|c|c|c|}
\hline $\begin{array}{c}\text { Urutan } \\
\text { Kriteria }\end{array}$ & Informan 1 & Informan 2 & Informan 3 & Informan 4 & Informan 5 & Informan 6 \\
\hline 1 & Networking & Dana & Networking & Networking & Networking & Dana \\
\hline 2 & Dana & $\begin{array}{c}\text { Metode } \\
\text { Pembelajaran }\end{array}$ & Dana & SDM & Dana & Networking \\
\hline 3 & $\begin{array}{c}\text { Metode } \\
\text { Pembelajaran }\end{array}$ & SDM & $\begin{array}{c}\text { Metode } \\
\text { Pembelajaran }\end{array}$ & Dana & $\begin{array}{c}\text { Metode } \\
\text { Pembelajaran }\end{array}$ & SDM \\
\hline 4 & Kurikulum & $\begin{array}{c}\text { Prasarana } \\
\text { dan Sarana }\end{array}$ & SDM & $\begin{array}{c}\text { Metode } \\
\text { Pembelajaran }\end{array}$ & Kurikulum & $\begin{array}{c}\text { Metode } \\
\text { Pembelajaran }\end{array}$ \\
\hline 5 & SDM & Kurikulym & Kurikulum & Kurikulum & Kurikulum & $\begin{array}{c}\text { Metode } \\
\text { Pembelajaran }\end{array}$ \\
\hline 6 & $\begin{array}{c}\text { Prasarana } \\
\text { dan Sarana }\end{array}$ & Networking & $\begin{array}{c}\text { Prasarana } \\
\text { dan Sarana }\end{array}$ & $\begin{array}{c}\text { Prasarana } \\
\text { dan Sarana }\end{array}$ & $\begin{array}{c}\text { Prasarana } \\
\text { dan Sarana }\end{array}$ & Kurikulum \\
\hline
\end{tabular}

Dari tabel 4.1 Kriteria Global Reputation di dapat bahwa prioritas yang paling penting untuk global reputation hampir sebagian besar informan memilih networking. Dana menempati urutan ke 2 dan metode Pembelajaran menepati urutan ke 3, hal ini disebabkan Networking sangat dibutuhkan untuk pengembangan kerjasama secara nasional maupun secara global kerjasama dibidang pendidikan dan segala factor yang menunjang terciptanya peserta didik yang berkualitas siap berkompetisi, sementara Dana merupakan salah satu modal utama untuk membesarkan/mengembangkan kelas internasional yang sudah ada, dan Metode Pembelajaran adalah salah satu cara yang paling tepat untuk menyampaikan materi ke peserta didik.

b. Kriteria National Reputation

Berikut ini adalah tabel urutan hasil dari hitungan kuesioner untuk kriteria national reputation

Tabel 4.2

Kriteria National Reputation

\begin{tabular}{|c|c|c|c|c|c|c|}
\hline $\begin{array}{c}\text { Urutan } \\
\text { Kriteria }\end{array}$ & $\begin{array}{c}\text { Informa } \\
\mathbf{n ~ 1 ~}\end{array}$ & Informan 2 & Informan 3 & Informan 4 & Informan 5 & Informan 6 \\
\hline 1 & $\begin{array}{c}\text { Networki } \\
n g\end{array}$ & SDM & Networking & Networking & Networking & Dana \\
\hline 2 & Dana & Dana & Dana & Dana & Dana & Networking \\
\hline 3 & Metode & Kurikulum & Metode & SDM & Metode & SDM \\
\hline
\end{tabular}




\begin{tabular}{|c|c|c|c|c|c|c|}
\hline & $\begin{array}{c}\text { Pembelaj } \\
\text { aran }\end{array}$ & & $\begin{array}{c}\text { Pembelajar } \\
\text { an }\end{array}$ & & $\begin{array}{c}\text { Pembelajar } \\
\text { an }\end{array}$ & \\
\hline 4 & SDM & Networking & SDM & $\begin{array}{c}\text { Metode } \\
\text { Pembelajar } \\
\text { an }\end{array}$ & SDM & Kurikulum \\
\hline 5 & $\begin{array}{c}\text { Kurikulu } \\
\text { m }\end{array}$ & $\begin{array}{c}\text { Prasarana } \\
\text { dan } \\
\text { Sarana }\end{array}$ & Kurikulum & Kurikulum & Kurikulum & $\begin{array}{c}\text { Metode } \\
\text { Pembelajar } \\
\text { an }\end{array}$ \\
\hline 6 & $\begin{array}{c}\text { Prasaran } \\
\text { a dan } \\
\text { Sarana }\end{array}$ & $\begin{array}{c}\text { Metode } \\
\text { Pembelajar } \\
\text { an }\end{array}$ & $\begin{array}{c}\text { Prasarana } \\
\text { dan } \\
\text { Sarana }\end{array}$ & $\begin{array}{c}\text { Prasarana } \\
\text { dan } \\
\text { Sarana }\end{array}$ & $\begin{array}{c}\text { Prasarana } \\
\text { dan } \\
\text { Sarana }\end{array}$ & $\begin{array}{c}\text { Prasarana } \\
\text { dan } \\
\text { Sarana }\end{array}$ \\
\hline
\end{tabular}

Dari Tabel 4.2 Kriteria National Reputation ternyata memiliki persamaan prioritas antara global reputation and reputation yaitu prioritas yang paling penting untuk global reputation hampir sebagian besar informan memilih Networking. Dana menempati urutan ke 2 dan Metode Pembelajaran menempati urutan ke 3, hal ini disebabkan Networking sangat dibutuhkan untuk mencapai target sebagai kelas internasional diperlukan Networking untuk pengembangan kerjasama secara nasional maupun secara global, kerjasama dibidang pendidikan dan segala faktor yang menunjang tercapainya peserta didik yang berkualitas siap berkompetisi, sementara Dana merupakan salah satu model utama untuk membesarkan/mengembangkan kelas internasional yang sudah ada, dan Metode Pembelajaran adalah suatu cara yang paling tepat untuk menyampaikan materi ke peserta didik.

c. Faktor SDM

Berikut ini adalah tabel urutan hasil dari hitungan kuesioner untuk faktor SDM

Tabel 4.3

Faktor SDM

\begin{tabular}{|c|c|c|c|c|c|c|}
\hline $\begin{array}{c}\text { Urutan } \\
\text { Kriteria }\end{array}$ & Informan 1 & Informan 2 & Informan 3 & Informan 4 & Informan 5 & Informan 6 \\
\hline 1 & $\begin{array}{c}\text { Kompetensi } \\
\text { Pedagogik }\end{array}$ & $\begin{array}{c}\text { Kompetensi } \\
\text { Pedagogik }\end{array}$ & $\begin{array}{c}\text { Kompetensi } \\
\text { Profesional }\end{array}$ & $\begin{array}{c}\text { Kompetensi } \\
\text { Profesional }\end{array}$ & $\begin{array}{c}\text { Kompetensi } \\
\text { Sosial }\end{array}$ & $\begin{array}{c}\text { Kompetensi } \\
\text { Sosial }\end{array}$ \\
\hline 2 & $\begin{array}{c}\text { Kompetensi } \\
\text { Sosial }\end{array}$ & $\begin{array}{c}\text { Kompetensi } \\
\text { Kepribadian }\end{array}$ & $\begin{array}{c}\text { Kompetensi } \\
\text { Sosial }\end{array}$ & $\begin{array}{c}\text { Kompetensi } \\
\text { Pedagogik }\end{array}$ & $\begin{array}{c}\text { Kompetensi } \\
\text { Kepribadian }\end{array}$ & $\begin{array}{c}\text { Kompetensi } \\
\text { Profesional }\end{array}$ \\
\hline 3 & $\begin{array}{c}\text { Kompetensi } \\
\text { Kepribadian }\end{array}$ & $\begin{array}{c}\text { Kompetensi } \\
\text { Profesional }\end{array}$ & $\begin{array}{c}\text { Kompetensi } \\
\text { Pedagogik }\end{array}$ & $\begin{array}{c}\text { Kompetensi } \\
\text { Sosial }\end{array}$ & $\begin{array}{c}\text { Kompetensi } \\
\text { Pedagogik }\end{array}$ & $\begin{array}{c}\text { Kompetensi } \\
\text { Kepribadian }\end{array}$ \\
\hline 4 & $\begin{array}{c}\text { Kompetensi } \\
\text { Profesional }\end{array}$ & $\begin{array}{c}\text { Kompetensi } \\
\text { Sosial }\end{array}$ & $\begin{array}{c}\text { Kompetensi } \\
\text { Kepribadian }\end{array}$ & $\begin{array}{c}\text { Kompetensi } \\
\text { Kepribadian }\end{array}$ & $\begin{array}{c}\text { Kompetensi } \\
\text { Profesional }\end{array}$ & $\begin{array}{c}\text { Kompetensi } \\
\text { Pedagogik }\end{array}$ \\
\hline
\end{tabular}

Dari tabel 4.3 Faktor SDM didapat bahwa prioritas yang paling penting untuk faktor SDM hampir sebagian besar informan memilih Kompetensi profesional, Kompetensi Pedagogik dan Kompetensi Sosial ini disebabkan Kompetensi Sosial merupakan kemampuan SDM untuk berkomunikasi dan bergaul secara efektif dengan peserta didik, tenaga kependidikan, orang tua/wali peserta didik, dan masyarakat sekitar. Sementara Pedagogik merupakan kemampuan pemahaman terhadap peserta didik, perancangan dan pelaksanaan pembelajaran, evaluasi hasil belajar, dan pengembangan peserta didik untuk mengaktualisasikan berbagai potensi yang dimilikinya. Kompetensi Kepribadian adalah kemampuan personal yang mencerminkan kepribadian yang mantap, stabil, dewasa, arif dan berwibawa, menjadi teladan bagi peserta didik, dan berakhlak mulia. Semua kompetensi pilihan informan ini merupakan kemampuan SDM profesional yang harus dimiliki agar dapat menunjang terwujudnya kelas internasional terkemuka.

Mutu pendidikan yang baik dapat mendorong terciptanya masyarakat yang berkualitasm kreatif dan produktif. Salah satu ciri dari mutu pendidikan yang baik 
adalah terciptanya proses pembelajaran yang baik pula (mulai dari perencanaan, pelaksanaan maupun evaluasi). Sebagai dampaknya SDM dalam hal ini tenaga pendidik yang merupakan peran sentral dalam proses pembelajaran sudah sewajarnya dituntut untuk lebih profesional dalam menjalankan fungsinya. Selain hal tersebut, perubahan dan perkembangan masyarakat yang semakin maju juga menuntut profesi tenaga pendidik atau SDM menyesuaikan diri dengan perubahan dan kebutuhan masyarakat nasional maupun internasional.

Disamping SDM memegang peranan penting untuk kualitas peserta didik yang dihasilkan. Materi pembelajaran juga menempati posisi yang sangat penting dari keseluruhan kurikulum, yang harus dipersiapkan agar pelaksanaan pembelajaran dapat mencapai sasaran. Sasaran tersebut harus sesuai dengan Standar Kompetensi dan Kompetensi Dasar yang harus dicapai oleh peserta didik. Artinya materi yang tentukan untuk kegiatan pembelajaran hendaknya materi yang benarbenar menunjang tercapainya standar kompetensi dan kompetensi dasar, serta tercapainya kualitas peserta didik.

d. Faktor Sarana dan Prasarana

Berikut ini adalah urutan hasil dari hitungan kuesioner untuk faktor Sarana dan Prasarana:

Tabel 4.4

Faktor Sarana dan Prasarana

\begin{tabular}{|c|c|c|c|c|c|c|}
\hline $\begin{array}{c}\text { Urutan } \\
\text { Kriteria }\end{array}$ & Informan 1 & Informan 2 & Informan 3 & Informan 4 & Informan 5 & Informan 6 \\
\hline 1 & Buku & $\begin{array}{c}\text { Air } \\
\text { Conditioner }\end{array}$ & $\begin{array}{c}\text { Air } \\
\text { Conditioner }\end{array}$ & $\begin{array}{c}\text { Air } \\
\text { Conditioner }\end{array}$ & LCD & LCD \\
\hline 2 & $\begin{array}{c}\text { Air } \\
\text { Conditioner }\end{array}$ & LCD & Perpustakaan & LCD & $\begin{array}{c}\text { Air } \\
\text { Conditioner }\end{array}$ & Air Conditioner \\
\hline 3 & Papan Tulis & Buku & Ruang Lab & Buku & Networking & Ruang Kelas \\
\hline 4 & $\begin{array}{c}\text { Perpustakaa } \\
\mathrm{n}\end{array}$ & Papan Tulis & Papan Tulis & Perpustakaan & Papan Tulis & Buku \\
\hline 5 & LCD & $\begin{array}{c}\text { Perpustakaa } \\
\mathrm{n}\end{array}$ & Buku & Papan Tulis & Perpustakaan & Papan Tulis \\
\hline 6 & $\begin{array}{c}\text { Gedung } \\
\text { Sekolah }\end{array}$ & $\begin{array}{c}\text { Gedung } \\
\text { Sekolah }\end{array}$ & LCD & Ruang Lab & $\begin{array}{c}\text { Gedung } \\
\text { Sekolah }\end{array}$ & Perpustakaan \\
\hline 8 & Ruang Kelas & Ruang Kelas & Ruang Kelas & $\begin{array}{c}\text { Gedung } \\
\text { Sekolah }\end{array}$ & Ruang Lab & Ruang Lab \\
\hline
\end{tabular}

Dari tabel 4.4 Faktor Sarana dan Perasarana didapat bahwa prioritas yang paling penting untuk faktor Sarana dan Prasarana hampir sebagian besar informan memilih air Conditioner, Liquid Crystal Display (LCD), dan papan tulis ini disebabkan ketika saya mengadakan wawancara kepada setiap informan sebelum pengisian kuesioner, sebagian besar mereka berpendapat perlunya Air Conditioner untuk memberikan rasa nyaman diruang kelas saat proses belajar mengajar terjadi. LCD merupakan salah satu fasilitas yang memudahkan tenaga pendidik maupun peserta didik disaat terjadinya proses belajar mengajar. Sementara buku merupakan pedoman atau acuan untuk mempermudah pemberian materi pelajaran termasuk dalam hal ini proses belajar mengajar.

e. Faktor Kurikulum

Berikut ini adalah tabel urutan hasil dari hitungan kuesioner untuk faktor kurikulum 
Tabel 4.5

Faktor Kurikulum

\begin{tabular}{|c|c|c|c|c|c|c|}
\hline $\begin{array}{c}\text { Urutan } \\
\text { Kriteria }\end{array}$ & $\begin{array}{c}\text { Informan } \\
\mathbf{1}\end{array}$ & $\begin{array}{c}\text { Informan } \\
\mathbf{2}\end{array}$ & $\begin{array}{c}\text { Informan } \\
\mathbf{3}\end{array}$ & $\begin{array}{c}\text { Informan } \\
\mathbf{4}\end{array}$ & $\begin{array}{c}\text { Informan } \\
\mathbf{5}\end{array}$ & $\begin{array}{c}\text { Informan } \\
\mathbf{6}\end{array}$ \\
\hline 1 & $\begin{array}{c}\text { Komponen } \\
\text { Strategi } \\
\text { PBM }\end{array}$ & $\begin{array}{c}\text { Komponen } \\
\text { Evaluasi }\end{array}$ & $\begin{array}{c}\text { Komponen } \\
\text { Strategi } \\
\text { PBM }\end{array}$ & $\begin{array}{c}\text { Komponen } \\
\text { Strategi } \\
\text { PBM }\end{array}$ & $\begin{array}{c}\text { Komponen } \\
\text { Strategi } \\
\text { PBM }\end{array}$ & $\begin{array}{c}\text { Komponen } \\
\text { Strategi } \\
\text { PBM }\end{array}$ \\
\hline 2 & $\begin{array}{c}\text { Komponen } \\
\text { Evaluasi }\end{array}$ & $\begin{array}{c}\text { Komponen } \\
\text { Strategi } \\
\text { PBM }\end{array}$ & $\begin{array}{c}\text { Komponen } \\
\text { Evaluasi }\end{array}$ & $\begin{array}{c}\text { Komponen } \\
\text { Evaluasi }\end{array}$ & $\begin{array}{c}\text { Komponen } \\
\text { Media }\end{array}$ & $\begin{array}{c}\text { Komponen } \\
\text { Evaluasi }\end{array}$ \\
\hline 3 & $\begin{array}{c}\text { Komponen } \\
\text { Tujuan }\end{array}$ & $\begin{array}{c}\text { Komponen } \\
\text { Tujuan }\end{array}$ & $\begin{array}{c}\text { Komponen } \\
\text { Media }\end{array}$ & $\begin{array}{c}\text { Komponen } \\
\text { Media }\end{array}$ & $\begin{array}{c}\text { Komponen } \\
\text { Tujuan }\end{array}$ & $\begin{array}{c}\text { Komponen } \\
\text { Tujuan }\end{array}$ \\
\hline 4 & $\begin{array}{c}\text { Komponen } \\
\text { Media }\end{array}$ & $\begin{array}{c}\text { Komponen } \\
\text { Isi/Materi }\end{array}$ & $\begin{array}{c}\text { Komponen } \\
\text { Tujuan }\end{array}$ & $\begin{array}{c}\text { Komponen } \\
\text { Tujuan }\end{array}$ & $\begin{array}{c}\text { Komponen } \\
\text { Evaluasi }\end{array}$ & $\begin{array}{c}\text { Komponen } \\
\text { Isi/Materi }\end{array}$ \\
\hline 5 & $\begin{array}{c}\text { Komponen } \\
\text { Isi/Materi }\end{array}$ & $\begin{array}{c}\text { Komponen } \\
\text { Media }\end{array}$ & $\begin{array}{c}\text { Komponen } \\
\text { Isi/Materi }\end{array}$ & $\begin{array}{c}\text { Komponen } \\
\text { Isi/Materi }\end{array}$ & $\begin{array}{c}\text { Komponen } \\
\text { Isi/Materi }\end{array}$ & $\begin{array}{c}\text { Komponen } \\
\text { Media }\end{array}$ \\
\hline
\end{tabular}

Dari tabel 4.5 Faktor Kurikulum dapat didapat bahwa prioritas yang paling penting untuk faktor kurikulum hampir sebagian besar informan memilih Komponen Strategi Proses Belajar Mengajar (PBM), Komponen Evaluasi dan Komponen Isi/Materi Pembelajaran karena berdasarkan kesimpulan wawancara saya kepada setiap informan sebagian besar mereka mengatakan strategi proses belajar mengajar merupakan hal yang sangat penting agar materi pembelajaran dengan mudah dapat diterima oleh peserta didik dan dalam hal ini harus mengetahui karakteristik peserta didik agar kitatahu strategi peoses belajar mengajar itu agar peserta didik memehami apa yang kita sampaikan dan bisa diterapkan didunia nyata saat nanti mereka terjun ke dunia kerja secara nasional atau global. Komponen evaluasi diperlukan agar bisa diukur sampai dimana tingkat pemahaman atau penerimaan atau kualitas peserta didik yang dipersiapkan untuk dapat bersaing secara nasional maupun secara global. Untuk mewujudkan hal tersebut maka diperlukan salah satunya materi pembelajaran (instructional materials) karena materi pembelajaran pada hakekatnya merupakan bagian tak terpisahkan dari Silabus, yakni perencanaan, prediksi dan proyeksi tentang apa yang akan dilakukan pada saat kegiatan pembelajaran.

Secara garis besar dapat dikemukakan bahwa materi pembelajaran adalah pengetahuan, keterampilan, dan sikap yang harus dikuasai peserta didik dalam rangka memenuhi standar komponen yang ditetapkan. Keberhasilan pembelajaran secara keseluruhan sangat tergantung pada keberhasilan SDM atau tenaga pendidik merancang materi pembelajaran dan berinteraksi dengan peserta didik dalam proses belajar mengajar. Materi pembelajaran adalah jenis, cakupan, urutan, dan perlakukan (treatment) terhadap materi pembelajaran tersebut. Agar pendidik dapat membuat persiapan yang berdaya guna dan berhasil guna, dituntut memahami berbagai aspek yang berkaitan dengan pengembangan materi pembelajaran, baik berkaitan dengan hakekat, fungsi, prinsip, maupun prosedur pengembangan materi serta mengukur efektivitas persiapan tersebut. Intinya materi pembelajaran menempati posisi yang sangat penting dari keseluruhan kurikulum dan tentunya semakin berkualitas bila didukung oleh faktor-faktor lainnya yang telah disebut diatas.

f. Faktor Metode Pembelajaran

Berikut ini adalah tabel urutan hasil dari perhitungan kuesioner untuk faktor metode pembelajaran: 
Tabel 4.6

Faktor Metode Pembelajaran.

\begin{tabular}{|c|c|c|c|c|c|c|}
\hline $\begin{array}{c}\text { Urutan } \\
\text { Kriteria }\end{array}$ & Informan 1 & Informan 2 & $\begin{array}{c}\text { Informan } \\
\mathbf{3}\end{array}$ & Informan 4 & Informan 5 & Informan 6 \\
\hline 1 & $\begin{array}{c}\text { Metode P. } \\
\text { Solving }\end{array}$ & $\begin{array}{c}\text { Metode } \\
\text { Sosiodrama }\end{array}$ & $\begin{array}{c}\text { Metode P. } \\
\text { Solving }\end{array}$ & $\begin{array}{c}\text { Metode } \\
\text { Tanya } \\
\text { Jawab }\end{array}$ & $\begin{array}{c}\text { Metode } \\
\text { Tanya } \\
\text { Jawab }\end{array}$ & $\begin{array}{c}\text { Metode P. } \\
\text { Solving }\end{array}$ \\
\hline 2 & $\begin{array}{c}\text { Metode } \\
\text { Diskusi }\end{array}$ & $\begin{array}{c}\text { Metode } \\
\text { Kelompok }\end{array}$ & $\begin{array}{c}\text { Metode } \\
\text { Kelompok }\end{array}$ & $\begin{array}{c}\text { Metode P. } \\
\text { Solving }\end{array}$ & $\begin{array}{c}\text { Metode } \\
\text { Kelompok }\end{array}$ & $\begin{array}{c}\text { Metode } \\
\text { Tanya } \\
\text { Jawab }\end{array}$ \\
\hline 3 & $\begin{array}{c}\text { Metode } \\
\text { Kelompok }\end{array}$ & $\begin{array}{c}\text { Metode P. } \\
\text { Solving }\end{array}$ & $\begin{array}{c}\text { Metode } \\
\text { Sosiodram }\end{array}$ & $\begin{array}{c}\text { Metode } \\
\text { Diskusi }\end{array}$ & $\begin{array}{c}\text { Metode } \\
\text { Sosiodrama }\end{array}$ & $\begin{array}{c}\text { Metode } \\
\text { Sosiodrama }\end{array}$ \\
\hline 4 & $\begin{array}{c}\text { Metode } \\
\text { Ceramah }\end{array}$ & $\begin{array}{c}\text { Metode } \\
\text { Diskusi }\end{array}$ & $\begin{array}{c}\text { Metode } \\
\text { Tanya } \\
\text { Jawab }\end{array}$ & $\begin{array}{c}\text { Metode } \\
\text { Kelompok }\end{array}$ & $\begin{array}{c}\text { Metode } \\
\text { Diskusi }\end{array}$ & $\begin{array}{c}\text { Metode } \\
\text { Kelompok }\end{array}$ \\
\hline 5 & $\begin{array}{c}\text { Metode } \\
\text { Tanya } \\
\text { Jawab }\end{array}$ & $\begin{array}{c}\text { Metode } \\
\text { Ceramah }\end{array}$ & $\begin{array}{c}\text { Metode } \\
\text { Diskusi }\end{array}$ & $\begin{array}{c}\text { Metode } \\
\text { Ceramah }\end{array}$ & $\begin{array}{c}\text { Metode P. } \\
\text { Solving }\end{array}$ & $\begin{array}{c}\text { Metode } \\
\text { Ceramah }\end{array}$ \\
\hline 6 & $\begin{array}{c}\text { Metode } \\
\text { Sosiodrama }\end{array}$ & $\begin{array}{c}\text { Metode } \\
\text { Tanya } \\
\text { Jawab }\end{array}$ & $\begin{array}{c}\text { Metode } \\
\text { Ceramah }\end{array}$ & $\begin{array}{c}\text { Metode } \\
\text { Sosiodrama }\end{array}$ & $\begin{array}{c}\text { Metode } \\
\text { Ceramah }\end{array}$ & $\begin{array}{c}\text { Metode } \\
\text { Diskusi }\end{array}$ \\
\hline
\end{tabular}

Dari tabel 4.6 Faktor Metode Pembelajaran didapat bahwa prioritas yang paling penting untuk faktor metode pembelajaran hampir sebagian besar informan memilih Metode Problem Solving. Metode Diskusi dan Tanya Jawab.

g. Faktor Dana

Berikut ini adalah tabel urutan hasil dari hitungan kuesioner untuk faktor dana :

Tabel 4.7

Faktor Dana

\begin{tabular}{|c|l|l|l|l|l|l|}
\hline $\begin{array}{c}\text { Urutan } \\
\text { Kriteria }\end{array}$ & Informan 1 & Informan 2 & Informan 3 & Informan 4 & Informan 5 & Informan 6 \\
\hline 1 & Masyarakat & Masyarakat & Masyarakat & Pemerintah & Masyarakat & Perusahaan \\
\hline 2 & Perusahaan & Perusahaan & Pemerintah & Masyarakat & Perusahaan & Pemerintah \\
\hline 3 & Pemerintah & Pemerintah & Perusahaan & Perusahaan & Pemerintah & Masyarakat \\
\hline
\end{tabular}

Dari tabel 4.7 Faktor Dana didapat bahwa keiteria yang paling penting untuk faktor dana hampir sebagian besar informan memilih Masyarakat, Pemerintah dan Perusahaan ini disebabkan kalau berbicara tentang kelas internasional tentunya erat kaitannya dengan orang tua dan peserta didik yang dalam hal ini mereka disebut juga masyarakat, dimana jelas dana terbesar untuk kelas internasional adalah dari masyarakat karena memasukan anaknya ke sekolah internasional atau kelas internasional adalah pilihan orang tua, jadi otomatis faktor dana dari masyarakat yang menempati urutan pertama, sementara pemerintah hanya sebagai faktor pendukung dalam pemberi dana karena dana pemerintah itu mengalir kebanyak sektor dan itu secara nasional tapi yang lebih penting pemerintah sebagai badan hukum yang mengawasi dan memberi rasa aman disana proses belajar mengajar berlangsung.

h. Faktor Networking

Berikut ini adalah urutan hasil dari hubungan keusioner untuk faktor networking

Tabel 4.8 
Faktor Networking

\begin{tabular}{|c|c|c|c|c|c|c|}
\hline $\begin{array}{c}\text { Urutan } \\
\text { Kriteria }\end{array}$ & Informan 1 & Informan 2 & Informan 3 & Informan 4 & Informan 5 & Informan 6 \\
\hline 1 & $\begin{array}{c}\text { Perguruan } \\
\text { Tinggi }\end{array}$ & $\begin{array}{c}\text { Perguruan } \\
\text { Tinggi }\end{array}$ & Perusahaan & Perusahaan & $\begin{array}{c}\text { Perguruan } \\
\text { Tinggi }\end{array}$ & Alumni \\
\hline 2 & Perusahaan & Perusahaan & $\begin{array}{c}\text { Perguruan } \\
\text { Tinggi }\end{array}$ & $\begin{array}{c}\text { Perguruan } \\
\text { Tinggi }\end{array}$ & Perusahaan & Perusahaan \\
\hline 3 & Alumni & Alumni & Alumni & Alumni & Alumni & $\begin{array}{c}\text { Perguruan } \\
\text { Tinggi }\end{array}$ \\
\hline
\end{tabular}

Dari tabel 4.8 Faktor Networking didapat bahwa kriteria yang paling untuk faktor Networking hampir sebagian besar informan memilih Perguruan Tinggi (dalam dan luar negeri). Perusahaan dan Alumni. Para informan memilih Perguruan Tinggi baik dalam maupun luar negeri yang menempati urutan pertama agar memudahkan menjalin kerjasama untuk kemajuan pendidikan secara nasional maupun global, seperti melalui pertukaran mahasiswa ataupun pertukaran dosen ataupun melakukan seminar antara perguruan tinggi tersebut secara nasional maupun global.

\section{F. Hasil Pembahasan}

Data yang didapat dari kuesioner berasal dari 6 informan yang merupakan akademis yang berkompeten dibidangnya masing-masing, kemudian dimasukkan kedalam tabel pengelompokkan dimana di dalam tabel tersebut merupakan angka perbandingan setiap kriteria, alternatif dan faktor. Dimana kriterianya adalah global reputation and national reputation, alternatifnya adalah SDM, kurikulum prasarana dan sarana, metode pembelajaran dan networking. Sementara bagian faktor adalah kompetensi kepribadian kompetensi pedagogik, kompetensi professional dan kompetensi sosial yang merupakan bagian dari alternatif SDM. Komponen tujuan, komponen isi/materi, komponen media, komponen strategi PBM dan komponen evaluasi merupakan bagian dari alternatif kurikulum. Gedung sekolah, ruang kelas, ruang Lab, perpustakaan, papn tulis, buku, LCD, air conditioner merupakan faktor-faktor dari alternatif alternatif prasarana dan sarana. Alternatif metode pembelajaran faktornya terdiri dari metode ceramah, metode tanya jawab, metode diskusi, metode kelompok, metode problem solving, dan metode sosiodrama. Untuk bagian alternatif dana, faktornya meliputi masyarakat, pemerintah dan perusahaan. Faktor terakhir berasal dari alternatif networking yang terdiri dari perusahaan, alumni dan perguruan tinggi dalam dan luar negeri. Kemudian dihitung eigen vector dari setiap faktornya dari alternatif/kriteria Eigen vector didapat dari penjumlahan nilai perbandingan setiap faktornya dimana sebelum didapat nilai perbandingannya, terlebih dahulu dilakukan perhitungan fraksi terhadap setiap factor dari keriteria tersebut. Nilai fraksi inilah yang akan dijumlahkan sehingga didapat nilai eigen vector.

Setelah didapat nilai eigen vector, maka kemudian dihitung nilai lamda $(\lambda)$ dengan menjumlahkan perkalian antara eigen vector dengan jumlah nilai perbandingan setiap kolomnya. Nilai lamda ini akan dijadikan basis perhitungan CR dimana sebelum menghitung CD (Consistent Ratio) dilakukan perhitungan $\mathrm{Cl}$ (Consistent Index) terlebih dahulu. Setelah didapat nilai $\mathrm{Cl}$ kmudian dihitung nilai $\mathrm{CR}$ dengan membagikan nilai $\mathrm{Cl}$ dengan nilai RI (Random Index).

\section{Data Gabungan}

Dari perhitungan setiap kriteria dan faktor di dapat hasil bahwa nilai CD lebih kecil atau sama dengan 0.1 atau 0.1 . Hal ini menunjukkan bahwa data yang didapt dari informan konsisten. Kekonsistenan in didapat karena setiap kriteria dan faktor 
mendapatkan nilai perbandingan yang tidak terlalu jauh atau mencolok sehingga nilai lamda tidak tertalu besar atau didapat nilai kecil sehingga data yang didapat konsisten. Apabilai nilai perbandingan setiap kriteria/faktor besar atau significant, maka nilai eigen vector akan besar sehingga nilai lamda besar dan diikuti nilai CR besar sehingga mengakibatkan data tidak konsisten. Hal ini menunjukkan bahwa setiap informan memberikan pendapat/opini untuk setiap faktor-faktor yang dibandingkan bisa dikatakan mendapat peranan/prioritas yang hampir sama pentingnya. Makna dari data-data yang diberikan informan menyatakan bahwa pengembangan pendidikan atau kelas internasional harus dilakukan disetiap faktor/aspek secara merata walaupun ada beberapa faktor yang harus diprioritaskan tetapi prioritas tersebut tidak terlalu mencolok dibandingkan dengan faktor/aspek yang lain. Untuk bagian data gabungan di dapat dari perwakilan nilai data yang paling banyak jumlahnya. Misalnya, dari 6 informan didapat untuk faktor SDM dibandingkan kurikulum, nilai 1 didapat dari 4 informan sedangkan 2 informan memberikan nilai lain selain angka 1 maka, frekuensi angka 1 lebih banyak/mayoritas sehingga nilai 1 yang mewakilkan angka gabungan.

Dari perhitungan nilai gabungan untuk semua kriteria dan faktor didapat nilai CR lebih kecil atau sama dengan 0.1 yang artinya juga konsisten. Hal ini didapat karena nilai dari sumbernya yaitu 6 informan yang juga merupakan data konsisten sehingga nilai gabungan juga cenderung konsisten. Makna yang didapat dari data gabungan ini adalah bahwa 6 informan secara mayoritas memberikan pendapat/opini terhadap faktorfaktor/aspek-aspek di study yang ada hampir sama. Ini memberikan indikasi bahwa sebenarnya para informan hampir memiliki satu pemikiran terhadap kondisi pendidikan dan satu pemikiran juga terhadap pengembangan pendidikan/kelas internasional.

\section{Perencanaan Kriteria}

Dari data yang didapat dari 6 informan maupun dari nilai gabungan di dapat bahwa prioritas yang paling penting untuk mengembangkan kelas internasional di tingkat nasional atau global reputation, maka yang paling penting adalah networking, dana dan metode pembelajaran. Hal ini menunjukkan bahwa untuk merencanakan pengembangan kelas internasional, harus dilakukan penjelajahan jaringan networking dahulu, pencarian dana dan perbaikan/pengembangan metode belajar yang tepat. Menjalin kerjasama dengan universitas dalam dan luar negeri seperti mengadakan seminar, pelatihan/pendidikan, pertukaran mahasiswa/dosen, study trip dan sebagainya merupakan langkah dalam pengembangan jaringan networking. Kerjasama dengan pemerintah, perusahaan dan orangtua peserta didik didalam menunjang kelancaran proses belajar mengajar, seperti pemberian beasiswa bagi peserta didik yang berprestasi dan sebagainya merupakan salah satu langkah untuk menggalang dana. Dalam penyampaian materi pembelajaran, pendidik harus mampu mentransfer ilmunya ke peserta didik dan untuk ini peserta didik diharuskan menguasai metodfe pembelajaran, sehingga materi yang diberikan bisa diterima oleh peserta didik secara total.

a. Perencanaan Faktor

1) Faktor SDM

Dalam data yang didapat dari 6 informan maupun dari nilai gabungan di dapat bahwa prioritas yang paling penting untuk mengembangkan kelas internasional untuk faktor SDM adalah kompetensi profesional, kompetensi pedagogik dan kompetensi sosial.

Dalam perencanaan pengembangan kelas internasional, kualitas SDM khususnya tenaga pendidik harus terus ditingkatkan sesuai dengna tuntutan zaman, seperti dengan menyekolahkan, memberikan pelatihan/training/seminar baik di dalam maupun luar negeri.

2) Faktor Sarana/Prasarana

Dari data yang didapat dari 6 informan maupun dari nilai gabungan di dapat bahwa prioritas yang paling penting untuk mengembangkan kelas internasional 
untuk faktor sarana dan prasarana adalah air conditioner, liquid crystal display ( $L C D$ ), dan papan tulis. Hal ini menunjukkan bahwa disaat terjadi kegiatan belajar mengajar kenyamanan ruangan, fasilitas dalam penyampaian materi pembelajaran merupakan faktor pendukung disaat terjadinya proses transfer ilmu dari pendidik ke peserta didik.

3) Faktor Kurikulum

Dari data yang di dapat dari 6 informan maupun dari nilai gabungan di dapat bahwa prioritas yang paling penting untuk mengembangkan kelas internasional untuk faktor kurikulum adalah komponen strategi proses belajar mengajar tersebut merupakan kunci tolak ukur kesuksesan dalam mentransfer materi pembelajaran yang akan diberikan, dan jika strategi yang diberikan salah maka proses belajar mengajar tidak sesuai dengan tujuan. Evaluasi juga memegang peranan sangat penting untuk mengukur tingkat pemahaman atau keberhasilan dari materi pembelajaran yang telah diberikan.

4) Faktor Metode Pembelajaran

Dari data yang di dapat dari 6 informan maupun dari nilai gabungan di dapat bahwa prioritas yang paling penting untuk mengembangkan kelas internasional adalah metode problem solving, metode diskusi dan tanya jawab. Hal ini disebabkanmetode problem solving akan membentuk peserta didik untuk mampu berpikir lebih kritis dan kreatif dalam memecahkan suatu masalah.

5) Faktor Dana

Dari data yang di dapat dari 6 informan maupun dari nilai gabungan di dapat bahwa prioritas yang paling penting untuk mengembangkan kelas internasional untuk faktor Dana adalah masyarakat, pemerintah dan perusahaan. Hal ini disebabkan kelas internasional tersebut sumber dana terbesarnya adalah dari masyarakat. Sementara pemerintah dan perusahan merupakan faktor pendukung.

6) Networking

Dari data yang di dapat dari 6 informan maupun dari nilai gabungan di dapat bahwa prioritas yang paling penting untuk mengembangkan kelas internasional adalah perguruan tinggi dalam dan luar negeri, perusahaan dan alumni. Hal ini di sebabkan lebih mudah untuk menjalin komunikasi dan kerja sama antar perguruan tinggi bila di bandingkan dengan pemerintah dan alumni.

\section{G. Kesimpulan}

Berdasarkan paparan data dan pembahasan hasil penelitian, maka secara umum dapat disimpulkan beberapa hal yaitu :

1. Perencanaan pengembangan kelas internasional terkemuka harus dilakukan secara terinci dan bertahap, harus diketahui apa goal/fokusnya, kriteria, alternatif dan faktor-faktor yang mendukung alternatif tersebut.

2. Global atau national reputation tidak bisa dibandingkan karena merupakan pilihan kerarah mana akan merencanakan pengembangan kelas internasional terkemuka tersebut karena untuk menjadi terkemuka bisa secara nasional maupun global.

3. Networking menempati prioritas pertama pada alternatif kriteria global reputation, dengan bobot 0.31 , Dana menempati urutan kedua dengan bobot 0.25 dan Metode Pembelajaran diurutan ke-3 dengan bobot 0.5 . Sementara pada national reputation Networking menempati urutan pertama dengan bobot 0,41, urutan keadua Dana dengan bobot 0.19 dan metode pembelelajaran urutan ketiga dengan bobot 0.12 .

4. Kompetensi profesional (0.33) menempati prioritas faktor pertama pada alternatif SDM, disusul kompetensi pedagogik diurutan kedua dengan bobot 0.24 dan urutan ketiga kompetensi sosial dengan bobot 0.24.

5. Pada alterantif sarana dan prasarana, air conditioner (0.21) menempati prioritas faktor pertama, kedua $L C D$ denga bobot( 0.17 dan urutan ketiga papan tulis dengan bobot $(0.16)$ 
6. Komponen strategi proses belajar mengajar (0.35) menempati prioritas faktor pertama pada alternatif kurikulum, urutan kedua dan ketiga komponen evaluasi dan komponen isi materi dengan bobot masing-masing (0.24) dan (0.15)

7. Metode problem solving (0.24) menempati prioritas faktor pertama pada alternatif metode pembelajaran, sementara diurutan kedua dan ketiganyametode diskusi dan metode tanya jawab, dengan bobot masing-masing (0.17) dan (0.16)

8. Masyarakat (0.66) menempati prioritas faktor pertama pada alteranatif dana, pemerintah dan perusahaan menempati diurutan kedua dan ketiga dengan bobot masing-masing $(0.18)$ dan $(0.16)$

9. Perguruan tinggi dalam/luar negeri (0.44) menempati prioritas faktor pertama dan alternatif networking, diikuti oleh perusahaan pada urutan kedua dan alumni diurutan ketiga dengan bobot masing-masing (0.32) dan (0.24).

\section{H. Daftar Pustaka}

2006. panduan penyusunan dan Implementasi Rencana Pengembangan Pendidikan Kabupaten / Kota.

Gall, Meredith D, Joyce R, Galt dan Walter R. Borg, 2003' Education Research . Amerika: Pearson Education, Inc.

Hasibuan, Malayu, s. P. 2002. Manajemen Sumber Daya Manusia' Bumi Aksara' Jakarta' Hani Hanndoko.2003. Manajemen. Edisi 2- Yogyakarta BPFE'

Juliyanti. 2011. Pemilihan Guru Berprestasi Menggunakan metode AHP dan TOPSIS (Technique for orders Reference by Similarity to Ideal Solution)' FMIPA ITS Surabaya.

Johannes Sinaga. 2009 Penerapan Analytic Hierarchy Process (AHP) dalam Pemilihan perusahaan badan Urulra Milik Negara (BUMN) sebagai tempat Kerja Mahasisrva Universitas Sumatera Utara (USU)", USU' Medan'

Kardi Teknomo.2009. Penggunaan Metode Analyic Hierrarchy Process dalam menganalisa Faktor-Faktor yang mempengaruhi Pemilihan Moda ke Kampus", Universitas Kristen Petra.

Kusrini. 2007. Konsep dan Aplikasi Sistem Pendukung Keputusan' Penerbit: Andi' Yogyakarta.

Martinis, Yamin dan Maisah. 2010. Standarisasi Kinerja Guru, Cetakan Pertama, Gaung Persada, Jakarta

Marsani Ash. 2010. Sistem Penunjang Keputusan Seleksi Mahasiswa Berprestasi 